\title{
Field verification of a light-driven model of biomass changes in the seagrass Halodule wrightii
}

\author{
Adrian B. Burd ${ }^{1, *}$, K. H. Dunton ${ }^{2}$ \\ ${ }^{1}$ Department of Oceanography, Texas A\&M University, College Station, Texas 77840-3146, USA \\ ${ }^{2}$ The University of Texas at Austin, Marine Science Institute, PO Box 1267, Port Aransas, Texas 78373, USA
}

\begin{abstract}
Underwater irradiance has frequently been cited as one of the most important, if not dominant, factors that regulates the distribution and productivity of seagrasses. Here we test that hypothesis in the development of a model to predict changes in the biomass of the seagrass Halodule wrightii Aschers based on the assumption that light is the dominant factor affecting growth. The model is a time-dependent, mechanistic model developed from above- and below-ground mass-balance and based on data collected in the Upper Laguna Madre, Texas, over a period of 9 yr from 1989 to 1997; the data set is ideally suited to testing the assumptions of the model. The data include regular measurements of above- and below-ground biomass coupled with continuous monitoring of underwater irradiance. Although the Upper Laguna suffered from a persistent brown tide from the summer of 1990 through the spring of 1996, the model was successful in reproducing trends in the observed above- and below-ground biomass. In particular, it captured the rapid recovery of the below-ground biomass as the brown tide bloom declined during spring 1996. Since agreement between the model and data decreases over a period of about $1 \mathrm{yr}$, some simple data-assimilation techniques were incorporated to help improve model performance. Close agreement between our model and in situ biomass measurements of $H$. wrightii collected over a 9 yr period reflect the importance of underwater light intensity as a major abiotic factor regulating seagrass productivity. In addition, the success of the model in predicting both above- and below-ground biomass demonstrates the importance of including both compartments in whole-plant modeling efforts that can be applied to coastal management practices. The demonstrated validity of a predictive whole-plant model for seagrass biomass will provide a valuable tool in the successful management of seagrass resources in coastal areas threatened by decreases in water transparency from anthropogenic impacts.
\end{abstract}

KEY WORDS: Seagrass · Halodule wrightii $\cdot$ Growth model

\section{INTRODUCTION}

Seagrass meadows are found in many coastal areas around the world. They help stabilize sediments (Christiansen et al. 1981), provide nursery habitats for fishes (Orth et al. 1984) and contribute significantly to the primary production in coastal and estuarine environments. Seagrasses are regarded as being indicators of the health of coastal ecosystems (Dennison et al. 1993), and recent die-offs occurring throughout the world have caused concern (Robblee et al. 1991, Quammen \& Onuf 1993).

*E-mail: adrian@halodule.tamu.edu
About $80 \%$ of the $950 \mathrm{~km}^{2}$ of seagrass meadows in Texas are found in the Laguna Madre (Pulich 1999). A loss of more than $140 \mathrm{~km}^{2}$ of seagrasses from the Laguna since the 1960 s has been attributed to decreases in water transparency arising from maintenance-dredging (Quammen \& Onuf 1993, Onuf 1994) and the occurrence of brown tide (Onuf 1996). The loss of seagrasses in Galveston Bay has been partially linked to decreased light levels arising from dredging and eutrophication effects (Pulich \& White 1991). Seagrass declines in Florida Bay have been variously attributed to increased eutrophication, reduced photosynthetic capability resulting from infection (Durako \& Kuss 1994), stress resulting from increased salinity

(C) Inter-Research 2001 
(Zieman et al. 1989) and increasing stagnation from the lack of major storms (Zieman et al. 1989). In many cases, determining the precise cause of the initial decline is hindered by the lack of data prior to and during the decline. Consequently there has been recent interest in using computer models to help identify the reasons for the die-offs and to assist in exploring measures to restore the system.

Several seagrass models already exist. These tend to concentrate on temperate species such as Zostera marina (Wetzel \& Neckles 1986) and Potamogeton perfoliatus (Madden \& Kemp 1996). Only 1 published model explicitly addresses the growth and biomass of Halodule wrightii (Fong \& Harwell 1994, Fong et al. 1997). In general, the modeling of seagrasses presents some interesting challenges, since many of the processes critical to seagrass production ecology are poorly understood. Models that attempt to incorporate these processes often have to rely on semi-empirical formulations which can vary between species and geographical location. For example, the most complex model for $H$. wrightii is the one presented by Fong \& Harwell 1994 and Fong et al. 1997). For that model, a semi-empirical relationship between productivity and biomass was developed which, for zero biomass, gives maximum productivity of the plants. Similar problems arise even in compiling the data that form the basis of these relationships. For example, Fong \& Harwell (1994) were unable to find data with which they could form a relationship between productivity and temperature for either $H$. wrightii or Syringodium filiforme.

Light is foremost among the factors crucial to seagrass production and growth (Zieman \& Wetzel 1980) and minimum light levels required to sustain various seagrass species have measured (Duarte 1991, Dunton 1994, Gallegos \& Kenworthy 1996, Kenworthy \& Fonseca 1996). Estimates of daily production derived from irradiance measurements have previously been made using the $H_{\text {sat }}$ model (Dennison \& Alberte 1982). This model, although providing an excellent index of daily production, is theoretically flawed (Richardson et al. 1983, Fourqurean \& Zieman 1991, Henley 1993, Zimmerman et al. 1994), and would have to be linked to models that convert daily productivity into changes in above- and below-ground biomass. Other factors influencing seagrass growth and production include, for example, nutrient availability and uptake rates (Lee \& Dunton 1999), sediment chemistry (Carlson et al. 1994) and disease (Durako \& Kuss 1994). Detailed information for many of these is limited.

Even though light is the dominant factor, there are very few long-term measurements of irradiance within seagrass beds. Since 1989 a monotypic meadow of Halodule wrightii Aschers in Upper Laguna Madre has been continuously monitored, with regular measurements of above- and below-ground biomass and continuous measurements of underwater irradiance. Since June of 1990, the characteristically clear waters (Pulich 1980) of the Upper Laguna have been affected by a persistent brown tide. The brown tide alga Aureoumbra lagunensis (class Pelagophyceae), unknown prior to the summer of 1990, reached cell concentrations exceeding $10^{6} \mathrm{ml}^{-1}$ (DeYoe \& Suttle 1994). Chlorophyll concentrations during the brown tide rarely fell below $20 \mathrm{mg} \mathrm{l}^{-1}$ and reached values as high as $90 \mathrm{mg} \mathrm{l}^{-1}$ (Stockwell et al. 1993). This has reduced light levels reaching the seagrass canopy; mean light transmission through the top $1 \mathrm{~m}$ of the water column dropped from $47 \%$ for the year preceding the brown tide to $19 \%$ during its first year (Onuf 1996). Dunton (1996) estimated the minimum light requirements for $H$. wrightii in the Laguna Madre as being $18 \%$ of surface irradiance (SI); Kenworthy \& Fonseca (1996) estimated the minimum light requirement for $H$. wrightii to lie between 14 and $27 \%$ SI (once correction was made for the fact that they measured SI just beneath the water surface). These values are similar to those estimates made by Dunton (1994) based on the significant impact of the brown tide on seagrass growth and production.

Data assimilation is being increasingly used in oceanographic, meterological and marine ecosystem models (Lawson et al. 1995, 1996, Anderson et al. 1996, Vallino 2000). Such techniques can be used to estimate the values of parameters in the model as well as to improve the model's short-term predictive capability. In the former case, model parameters are adjusted until satisfactory agreement is achieved between model results and observations. Differences between model results and observed time-series often increase if the model is run for long periods of time. This can be countered by periodically reinitializing the model using data values, forcing the model back into agreement with the data.

Here, we report on the development of a mathematical model for the growth and biomass of Halodule wrightii. There are many approaches to formulating a mathematical model. One is to include as many relevant processes as possible (see Fong \& Harwell 1994, Madden \& Kemp 1996, Short 1980); this approach is well-suited to data-rich systems such as the Chesapeake Bay (Madden \& Kemp 1996). More commonly, it is often better to develop a model that concentrates on only a few dominant processes. We have followed the latter approach. Such a model has the advantage of making it easier to see where the model can be improved and where there are gaps in our knowledge and understanding. Close collaboration between field scientists and modelers can then proceed to help fill these gaps. 
The model of Halodule wrightii presented here fills a gap in existing models in that it is a whole-plant approach; changes in below-ground biomass are explicitly included. A crucial assumption in the formulation of the model is that light is the dominant factor determining production and growth of the whole plant. The long-term time-series of biomass and irradiance measurements allow us to both test and validate this assumption. Development of the model will also help identify avenues of research important to further development of seagrass models.

\section{METHODS}

Data collection. Measurements of plant biomass and underwater irradiance were made at Site LM-151 $\left(27^{\circ} 21^{\prime} \mathrm{N}, 97^{\circ} 22^{\prime} \mathrm{W}\right)$ in the Laguna Madre, Texas, USA (Fig. 1). Plant biomass samples were collected at 1 to 3 mo intervals from May 1989 to September 1997. Sampling was conducted within a monotypic stand of Halodule wrightii Aschers at a depth of $1.3 \mathrm{~m}$.

Estimates of plant biomass were made following the procedures outlined in Dunton (1990, 1994). During each trip, 4 replicate samples were collected using a $9 \mathrm{~cm}$ coring device. Samples were thoroughly cleaned of any sediment and other material and separated into

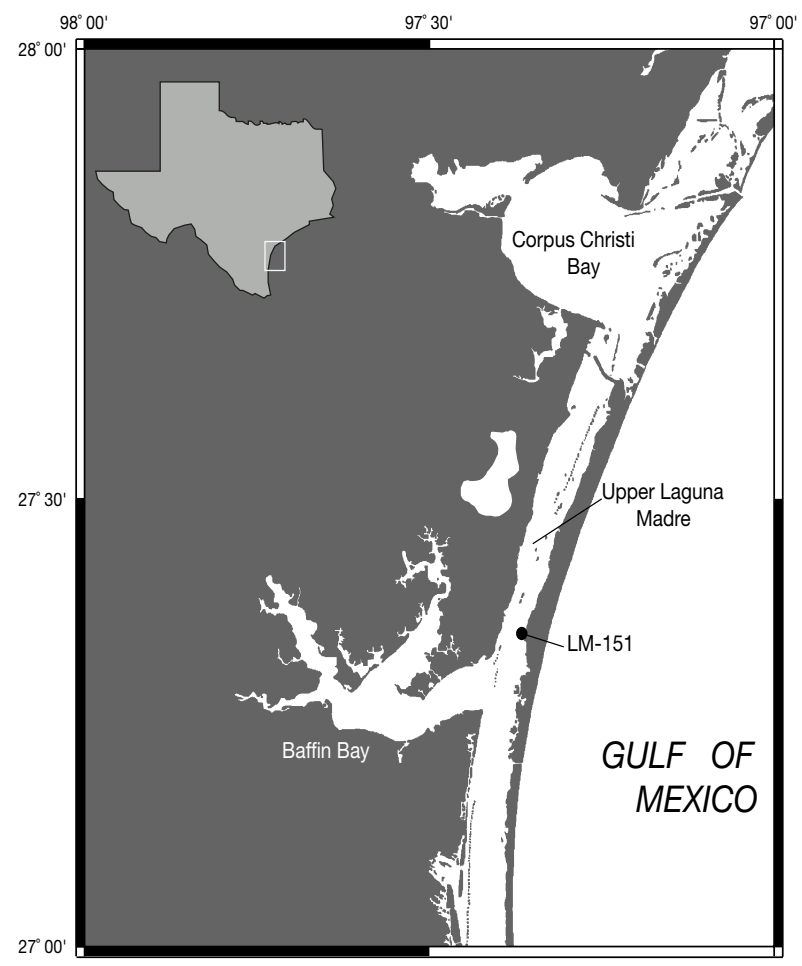

Fig. 1. Location of sampling site (LM-151) situated in the Upper Laguna Madre, Texas, between Corpus Christi Bay and Baffin Bay above- and below-ground live biomass. For consistency and to avoid uncertainty with respect to the location of plant tissues at the dynamic sediment-water interface, above-ground biomass is defined to include only green-pigmented tissues. This would include all leaf tissues, but excludes horizontal and vertical rhizomes and roots which are not pigmented and normally buried in the sediment. Separation of live and dead material was based on obvious differences in color, buoyancy, and texture of the tissues. The sorted material was dried at $60^{\circ} \mathrm{C}$ to a constant weight and the results expressed as above- and below-ground biomass ( $g$ dry wt $\mathrm{m}^{-2}$ ) collected in each core.

Measurements of photosynthetically active radiation (PAR) (400 to $700 \mathrm{~nm}$ ) at the canopy level were collected continuously using a LI-193SA spherical $(4 \pi)$ quantum sensor that provided input to a LI-1000 data-logger (LiCor Inc., Lincoln, Nebraska, USA). The data-logger was enclosed in a weighted, clear polycarbonate housing (Ikelite Model 5910, Indianapolis, Indiana, USA) and connected to the sensor cable using a moulded underwater connector (Crouse-Hinds Series 41 Penetrator, La Grange, North Carolina, USA). Stainless-steel bands were used to secure the lid, and the housing was placed within a plastic bag and buried in the seabed to reduce both corrosion and the likelihood of discovery by fishermen. The data-logger was serviced at 2 to 3 mo intervals. The sensor itself was mounted at canopy level (15 to $20 \mathrm{~cm}$ above the bottom) on a $3 \mathrm{~cm}$ PVC pipe to minimize fouling by drift algae and seagrass leaves. The sensor was cleaned regularly (1 to 3 wk intervals), although fouling was minimal because the brown tide bloom greatly reduced the colonization of fouling organisms due to the persistent low light levels and its high density (1 million cells ml ${ }^{-1}$; DeYoe \& Suttle 1994).

Several gaps, sometimes several days in length, were present in the light record. It is impossible to accurately recover the values of the missing data. The data gaps were filled by first identifying the gap, and then filling it with a data record of the same length taken from the data directly before the gap occurred. Assuming that the statistics of the light field do not change appreciably over time scales of a few days, this procedure will fill the gaps with reasonable values.

The model. The model combines simplicity with the assumption that light is the main factor affecting seagrass growth. Hence, carbon was used as the currency for the model and PAR was the only forcing function. Two compartments were used, one for above-ground biomass and the other for below-ground biomass with transport of material from the above- to the belowground tissue. Since nutrient uptake was not included, the below-ground compartment was used only for storage. Both above- and below-ground compartments were affected by structural loss and respiration. 
The model uses several parameters (e.g., carrying capacity) whose values are unknown. These were obtained by a least-squares technique using model results and the observed biomass and underwater irradiance measurements from 1989; this year was chosen since it was before the brown tide was observed in Laguna Madre. Both 1996 and 1997 were characterized by low concentrations of brown tide, but these years also represent a period of recovery from prolonged light limitation.

Underwater irradiance measured at canopy level was used in both the development and calibration of the model. For simulations where model results were compared to field observations of biomass, measured in situ light data were used. Additional simulations were made using a synthetic annual light cycle in which the SI on a given day was calculated by averaging data from a time-series of SI measured in the Laguna Madre between August 1994 and February 1997. Values for the same time on the same Julian day each year were averaged to produce a time-series of $1 \mathrm{yr}$ in length. Because of the non-integer number of years in the original time-series and the fact that some days had some data missing, each average was from between 2 and 4 data values. Light irradiance at the plant canopy level was calculated using Beer's law:

$$
I(z)=I(0) \exp (-k z)
$$

where $I(0)$ is the SI, $I(z)$ the irradiance at depth $z$ within the water column, and $k$ is the attenuation coefficient whose value was chosen for each particular simulation. Effects of scattering at the air-water interface were taken into account assuming a flat interface and using Fresnel's equations (Kirk 1994). The specific gross production $(P)$ at irradiance $I$ was then calculated using a Jassby-Platt parameterization (Jassby \& Platt 1976):

$$
P(I)=P_{\max } \tanh \left(\frac{I}{I_{k}}\right)
$$

Table 1. Parameter values used in the model. Production and respiration values were converted from oxygen to carbon assuming photosynthetic and respiration efficiencies of 1 . Values for structural loss were determined from personal observation in the field. See 'Methods' and Table 3 for explanations of the parameters

\begin{tabular}{|lll|}
\hline Parameter & \multicolumn{1}{c|}{ Value } & \multicolumn{1}{c|}{ Source } \\
\hline$P_{\max }$ & $422 \mathrm{mmol} \mathrm{O}_{2}{\mathrm{~g} \mathrm{dry} \mathrm{wt}^{-1} \mathrm{~h}^{-1}}$ & Dunton (1996) \\
$I_{\mathrm{k}}$ & $319 \mathrm{mmol} \mathrm{m}^{-2} \mathrm{~s}^{-1}$ & Dunton (1996) \\
$R_{\mathrm{a}}$ & $41.5 \mathrm{mmol} \mathrm{O}_{2} \mathrm{~g} \mathrm{dry} \mathrm{wt}^{-1} \mathrm{~h}^{-1}$ & Dunton \& Tomasko (1994) \\
$R_{\mathrm{b}}$ & $16.1 \mathrm{mmol} \mathrm{O}_{2} \mathrm{gdry} \mathrm{wt}^{-1} \mathrm{~h}^{-1}$ & Dunton \& Tomasko (1994) \\
$M_{\mathrm{a}}$ & $0.004 \mathrm{~d}^{-1}$ & \\
$M_{\mathrm{b}}$ & $0.0004 \mathrm{~d}^{-1}$ & \\
\hline
\end{tabular}

where $I_{k}$ is the saturation irradiance and $P_{\max }$ the maximum specific production. Values for $P_{\max }$ and $I_{k}$ were obtained from measurements made within the Laguna Madre (Dunton \& Tomasko 1994), and are shown in Table 1 with other parameters used in the simulations. Self-shading within the plant canopy limits the total amount of production at high shoot densities. This was modeled using a logistic function to modify Eq. (2) to give

$$
P\left(I, C_{a}\right)=P_{\max } \tanh \left(\frac{I}{I_{k}}\right)\left(1-\frac{C_{\mathrm{a}}}{\kappa}\right)
$$

where $C_{\mathrm{a}}$ is the above-ground biomass. The parameter $\mathrm{\kappa}$ is the carrying capacity of the canopy and was determined using a least-squares technique as described above.

Sinks of carbon within a unit area of seagrass bed include respiration, leaf loss, mortality of above- and below-ground material, grazing etc. Measurements were available for plant respiration (see $R_{\mathrm{a}}, R_{\mathrm{b}}$ in Table 1). All other loss rates were combined into 'structural loss'. Both respiration and structural loss for both the above- and below-ground compartments were assumed to depend linearly on the biomass of each compartment. For example, above-ground respiration and structural-loss rates had the forms $R_{\mathrm{a}} C_{\mathrm{a}}$ and $M_{\mathrm{a}} C_{\mathrm{a}}$ respectively. Values that were used for the respiration rates $\left(R_{\mathrm{a}}\right.$ and $\left.R_{\mathrm{b}}\right)$ and specific structural-loss rates $\left(M_{\mathrm{a}}\right.$ and $M_{\mathrm{b}}$ ), are shown in Table 1 .

Temperature can significantly affect the rates of physiological processes such as photosynthesis and respiration (Thornley \& Johnson 1990). The water column was assumed to be well mixed, with a temperature, $T$, at time $t$ determined from:

$$
T(t)=21.0+9.0 \sin \left(\frac{2 \pi t}{365}-\frac{\pi}{2}\right)
$$

This expression was obtained by fitting a sine function to data taken from Lower Laguna Madre (Brown 1997). Photosynthetic parameters and respiration rates for Halodule wrightii have been measured over a range of temperatures, both in the laboratory and in situ (Dunton \& Tomasko 1994). Comparisons between in situ and laboratory measurements for Thalassia testudinum showed that in situ whole-plant production measurements are more reliable than laboratory measurements (Herzka \& Dunton 1997). Unfortunately, in situ measurements for $H$. wrightii show considerable variability. For example, estimates of $P_{\max }$ at $22^{\circ} \mathrm{C}$ can be 5 times greater than those measured at $30^{\circ} \mathrm{C}$ (Dunton 1996). Consequently, we modeled the temperature dependence of production and respiration using an Ahrrenius formulation (Thornley \& Johnson 1990): 

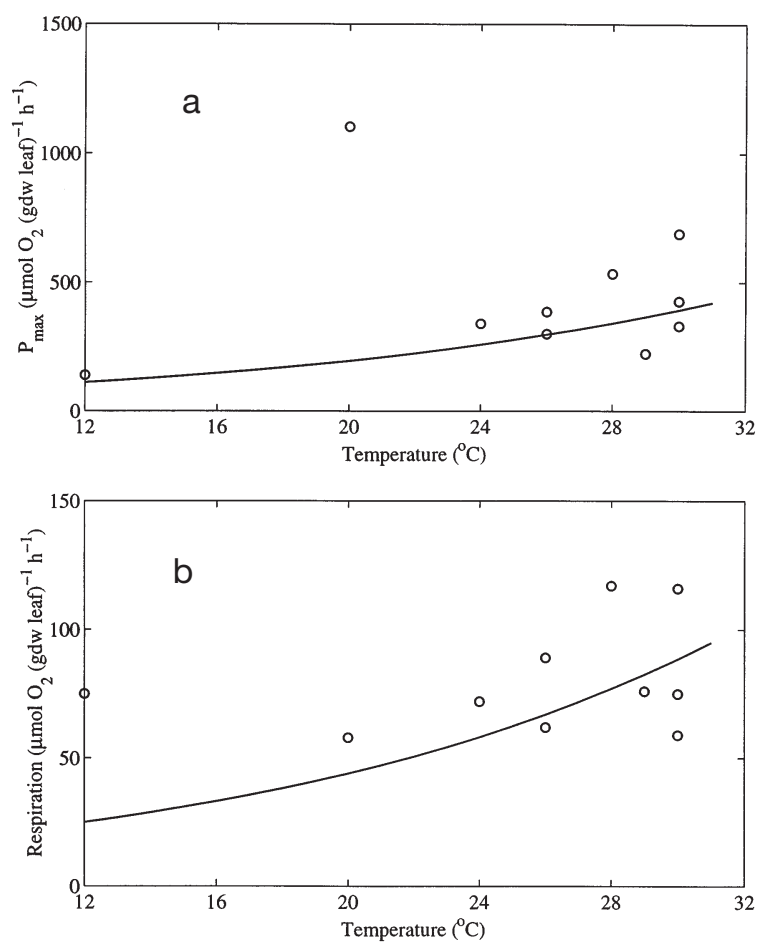

Fig. 2. Comparison of observed and theoretical changes of maximum gross production $\left(P_{\max }\right)$ and respiration with changing temperature. (O) Data from Dunton \& Tomasko (1994); line: model formulation based on the Ahrrenius formulation

$$
\Gamma(T)=\Gamma_{0} \exp \left\{\zeta\left[T(\mathrm{t})-T_{0}\right]\right\}=\Gamma_{0} \exp (\zeta \Delta T)
$$

where $\Gamma$ is the physiological parameter of interest (e.g., respiration), $T$ is the temperature and $\Gamma_{0}$ is the value of $\Gamma$ measured at temperature $T_{0}$ (in this case $31^{\circ} \mathrm{C}$ ). In this study, the parameter $\zeta=0.07$ was chosen such that $Q_{10}=2$, a value typical of marine organisms (Valiela 1995). With the exception of an outlier (a high $P_{\max }$ at $22^{\circ} \mathrm{C}$ ), there is generally good agreement between the data collected by Dunton \& Tomasko (1994) and the Ahrrenius formulation (Fig. 2).

The below-ground biomass of Halodule wrightii can account for as much as 60 to $80 \%$ of the total plant biomass (Dunton 1996). This below-ground material is supported by photosynthetically produced carbon (Smith et al. 1984, Caffrey \& Kemp 1991, Ralph et al. 1992) which is stored in the rhizome and used to maintain the plant during periods of low photosynthetic production (Pirc 1989, Lee \& Dunton 1996). Little is known about how seagrasses allocate resources, although carbon is stored in the rhizomes as carbohydrates (Pirc 1985, Dawes \& Guiry 1992). Transport of material occurs both vertically between leaves and rhizomes (Dawes \& Lawrence 1979, 1980, Pirc 1985, Dawes \& Guiry 1992, Lee \& Dunton 1996, 1999) and horizontally along the ramet (Lee \& Dunton 1999). In
Table 2. Values of the 3 parameters obtained by calibration of the model with observational data for the year 1989. See

'Methods' and Table 3 for explanations of the parameters

\begin{tabular}{|cc|}
\hline Parameter & Value \\
\hline$\kappa$ & $667.0 \mathrm{~g} \mathrm{dry} \mathrm{wt} \mathrm{m}^{-2}$ \\
$\tau$ & 0.34 \\
$\delta$ & 0.001 \\
\hline
\end{tabular}

the simple model used here, only transport from the above- to the below-ground component is considered. Various formulations for transport in both directions were examined, but only the simple model used here resulted in convergence between the data and the model results. The formulation we used assumes that transport is proportional to the gross production of the plant

$$
\text { Transport }=\tau P\left(I, C_{\mathrm{a}}\right)
$$

The value of $\tau$ obtained from model calibration is given in Table 2 .

Seagrasses release dissolved organic carbon (DOC) into the sediments (Moriarty et al. 1986) and this can provide an additional loss of carbon from the plant. For the sake of simplicity, we again assumed that the rate of DOC loss was proportional to gross production with a proportionality factor $\delta$ determined from model calibration (see Table 2).

The resulting equations determining the evolution of the above-ground $\left(C_{\mathrm{a}}\right)$ and below-ground $\left(C_{\mathrm{b}}\right)$ biomass were

$$
\begin{aligned}
& \frac{\mathrm{d} C_{\mathrm{a}}}{\mathrm{d} t}=(1-\tau) P(I) e^{k \Delta T} C_{\mathrm{a}}\left(1-\frac{C_{\mathrm{a}}}{\kappa}\right)-R_{\mathrm{a}} e^{k \Delta T} C_{\mathrm{a}}-M_{\mathrm{a}} C_{\mathrm{a}} \\
& \frac{\mathrm{d} C_{\mathrm{b}}}{\mathrm{d} t}=(\tau-\delta) P(I) e^{k \Delta T} C_{\mathrm{a}}\left(1-\frac{C_{a}}{\kappa}\right)-R_{\mathrm{b}} e^{k \Delta T} C_{\mathrm{b}}-M_{\mathrm{b}} C_{\mathrm{b}}
\end{aligned}
$$

The model was programmed using Matlab (Matlab is a trademark of The Mathworks Inc. Natick, MA) and run on a Digital Alpha UNIX workstation. Several parameters $(\tau, \kappa$ and $\delta$ ) whose values are unknown are used in the model. These were obtained using the constrained nonlinear optimization routine contained in the Matlab optimization toolbox ${ }^{1}$, using model results and the observed biomass and underwater irradiance measurements from 1989, before the brown tide was observed in Laguna Madre. The bloom abated in 1996 and 1997, allowing the plants to recover from prolonged light-limitation. The results of

\footnotetext{
${ }^{1}$ The optimization routine used a sequential quadratic programming method in which estimates of the Hessian and Lagrangian were updated at each iteration (Grace 1993)
} 
Table 3. Symbols and parameters used in present study

\begin{tabular}{|c|c|c|}
\hline Symbol & Parameter & Measure \\
\hline$t$ & Time & d \\
\hline$I_{0}$ & SI & $\mu \mathrm{mol} \mathrm{m} \mathrm{m}^{-2} \mathrm{~s}^{-1}$ \\
\hline$I(z)$ & Irradiance at depth $z$ & $\mu \mathrm{mol} \mathrm{m} \mathrm{m}^{-2} \mathrm{~s}^{-1}$ \\
\hline$z$ & Water depth & $\mathrm{m}$ \\
\hline$k$ & Water column attenuation & $\mathrm{m}^{-1}$ \\
\hline$\zeta$ & Parameter in temperature relation & \\
\hline$P$ & Gross production & $\mu \mathrm{mol} \mathrm{O} \mathrm{g}^{-1}$ dry wt $\mathrm{h}^{-1}$ \\
\hline$P_{\max }$ & Maximum gross production & $\mu \mathrm{mol} \mathrm{O} \mathrm{g}^{-1}$ dry wt $\mathrm{h}^{-1}$ \\
\hline$I_{k}$ & Saturation irradiance & $\mu \mathrm{mol} \mathrm{m} \mathrm{m}^{-2} \mathrm{~s}^{-1}$ \\
\hline$C_{\mathrm{a}}$ & Above-ground biomass & $\mathrm{g}$ dry wt $\mathrm{m}^{-2}$ \\
\hline$C_{\mathrm{b}}$ & Below-ground biomass & g dry wt $\mathrm{m}^{-2}$ \\
\hline$\kappa$ & Carrying capacity & g dry wt $\mathrm{m}^{-2}$ \\
\hline$T$ & Temperature & ${ }^{\circ} \mathrm{C}$ \\
\hline$R_{\mathrm{a}}$ & Above-ground respiration & $\mu \mathrm{mol} \mathrm{O} \mathrm{g}^{-1}$ dry wt $\mathrm{h}^{-1}$ \\
\hline$R_{\mathrm{b}}$ & Below-ground respiration & $\mu \mathrm{mol} \mathrm{O} \mathrm{g}^{-1}$ dry wt $\mathrm{h}^{-1}$ \\
\hline$M_{\mathrm{a}}$ & Above-ground mortality & $d^{-1}$ \\
\hline$M_{\mathrm{b}}$ & Below-ground mortality & $d^{-1}$ \\
\hline$\delta$ & DOC release & As fraction of production \\
\hline
\end{tabular}

this model calibration are shown in Table 2. Once calibrated, the model was run both with and without the assimilation of field biomass data to reset the model at the beginning of each $1 \mathrm{yr}$ simulation. When run without data assimilation, the differential equations (Eqs. $7 \&$ 8) were solved using initial conditions for $C_{\mathrm{a}}$ and $C_{\mathrm{b}}$ and underwater irradiance as the sole forcing function.

Simple data-assimilation techniques were used to minimize drift between model results and observations. To do this, the model was started as before, solving Eqs. (7) \& (8) using the same initial conditions for $C_{\mathrm{a}}$ and $C_{\mathrm{b}}$ and forcing the model with the observed underwater irradiance. The equations were integrated for a $1 \mathrm{yr}$ simulation period; $C_{\mathrm{a}}$ and $C_{\mathrm{b}}$ were then re-initialized using the first observed values of that year. The equations were again integrated for $1 \mathrm{yr}$ and the process repeated. Table 3 summarizes the symbols and parameters used.

\section{RESULTS}

\section{Field data and model calibration}

The underwater irradiance (Fig. 3) showed a strong seasonal signal as well as a decline from 1990 through

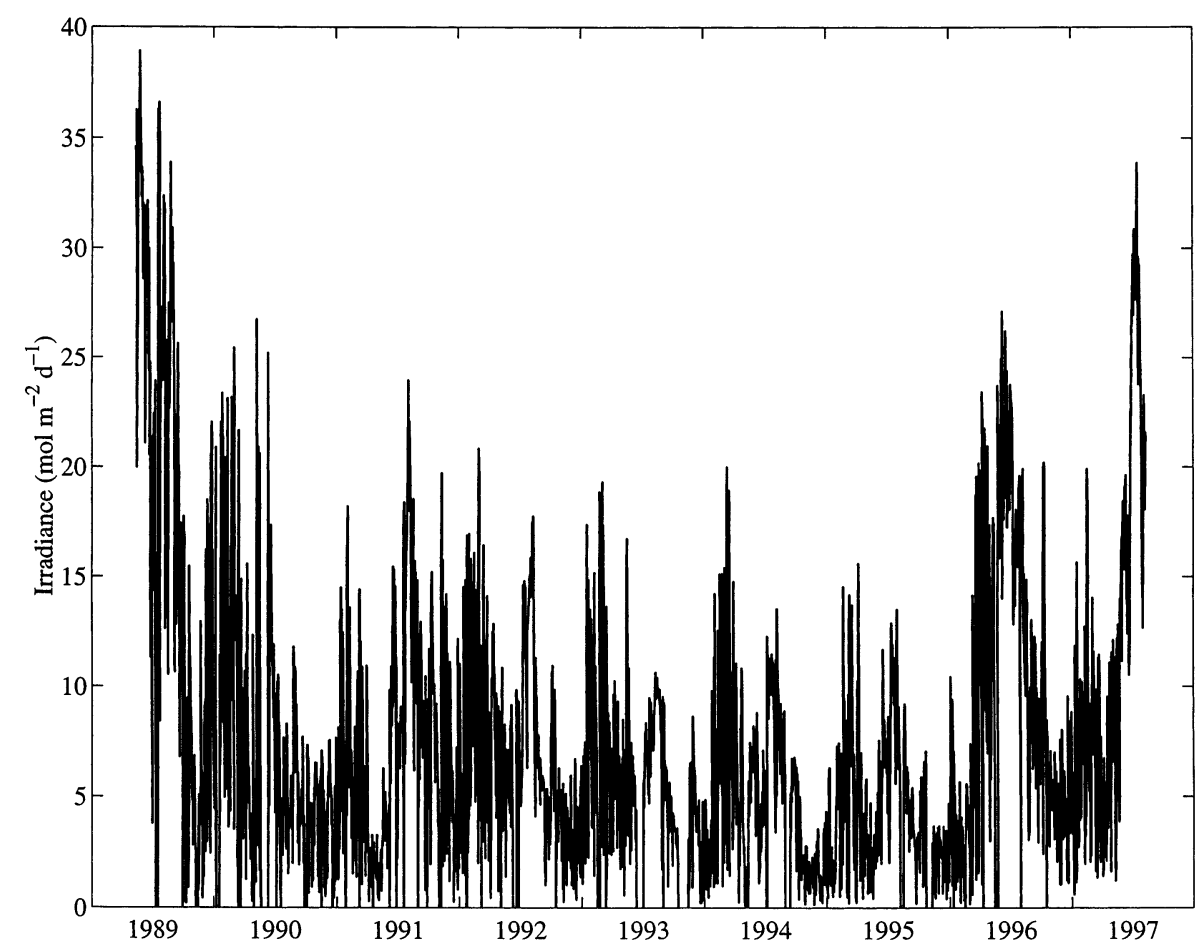

Fig. 3. Daily irradiance (PAR, mol photons) measured at the canopy level at Site LM-151 from May 1989 through August 1997. A long-lived brown tide algal bloom resulted in lowered irradiances from 1990 through 1995 

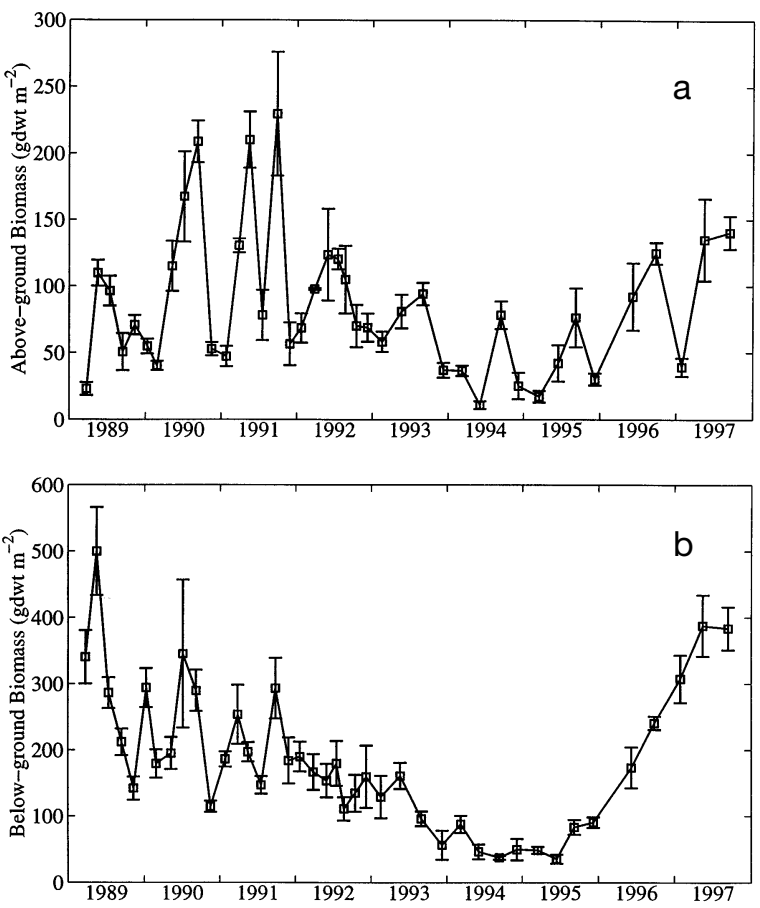

Fig. 4. Halodule wrightii. Biomass at Site LM-151 between March 1989 and September 1997. Error bars: \pm SE. Both (a) above- and (b) below-ground biomass showed declines attributed to decreased light levels; the below-ground biomass showed a faster recovery than the above-ground bio mass as the brown tide decreased in 1995

1995 as a result of the brown tide. In 1989, 1 yr before the brown tide bloom began, underwater irradiance peaked at $38.9 \mathrm{~mol}$ photons $\mathrm{m}^{-2} \mathrm{~d}^{-1}$. During the brown tide, peak irradiances fell steadily, reaching a minimum of $15.6 \mathrm{~mol}$ photons $\mathrm{m}^{-2} \mathrm{~d}^{-1}$ in 1995. By late 1997 , following abatement of the bloom, values as high as $33.8 \mathrm{~mol}$ photons $\mathrm{m}^{-2} \mathrm{~d}^{-1}$ were recorded. Abatement began in winter 1995/1996, as reflected in the subsequent 18 mo period in which canopy-level irradiances were comparable to those before the onset of the brown tide.

The above- (Fig. 4a) and below-ground biomass (Fig. 4b) of Halodule wrightii also showed both a seasonal cycle and a decline. The above-ground biomass first showed the effect of reduced irradiance between 1991 and 1992, when the peak biomass dropped from 229 to $124 \mathrm{~g}$ dry wt $\mathrm{m}^{-2}$. The maximum annual aboveground biomass continued to decline, reaching a minimum of $76 \mathrm{~g}$ dry wt $\mathrm{m}^{-2}$ in 1995 before returning to values similar those seen in 1989. The below-ground biomass followed a slightly different pattern, with a continuous decline from a maximum of $500 \mathrm{~g}$ dry wt $\mathrm{m}^{-2}$ in 1989 to $90 \mathrm{~g}$ dry wt $\mathrm{m}^{-2}$ in 1995 . In 1996 and 1997, the below-ground biomass recovered rapidly, reaching a peak of $387 \mathrm{~g}$ dry $\mathrm{wt} \mathrm{m}^{-2}$ in 1997 . The total plant biomass behaved in a manner similar to the below-ground material, with a peak value of $610 \mathrm{~g}$ dry wt $\mathrm{m}^{-2}$ in 1989 followed by a steady decline to a maximum of $166 \mathrm{~g}$ dry wt m ${ }^{-2}$ in 1995.

After calibration, the model was run while being forced with the observed underwater irradiance for the years 1990 to 1997 (Fig. 3). Above- and below-ground biomasses measured in January of 1990 were used as initial values for the model. The model results showed a clear seasonal signal and tracked the decline of both the above- (Fig. 5a) and below- (Fig. 5b) ground biomass between 1992 and 1996.

Three separate periods were apparent when the model results did not agree well with observed biomass. For the first 2 yr (1990 and 1991) the model under-predicted both the above- and below-ground biomass. The model did not replicate the variation that is seen in the measured above-ground values. For example, towards the end of 1990, the observed biomass dropped from over $200 \mathrm{~g}$ dry $\mathrm{wt} \mathrm{m}^{-2}$ to approximately $50 \mathrm{~g}$ dry $\mathrm{wt} \mathrm{m}^{-2}$ (Fig. 5a), whereas the peak in the model results was approximately $120 \mathrm{~g}$ dry wt $\mathrm{m}^{-2}$. The measured below-ground values showed a similar variation to those above-ground, but these were also not reflected in the model results. Instead, the belowground model results showed a steady decline from 300 to approximately $100 \mathrm{~g}$ dry wt $\mathrm{m}^{-2}$.

Observed and simulated biomass were in better agreement between 1992 and 1995. During this period,
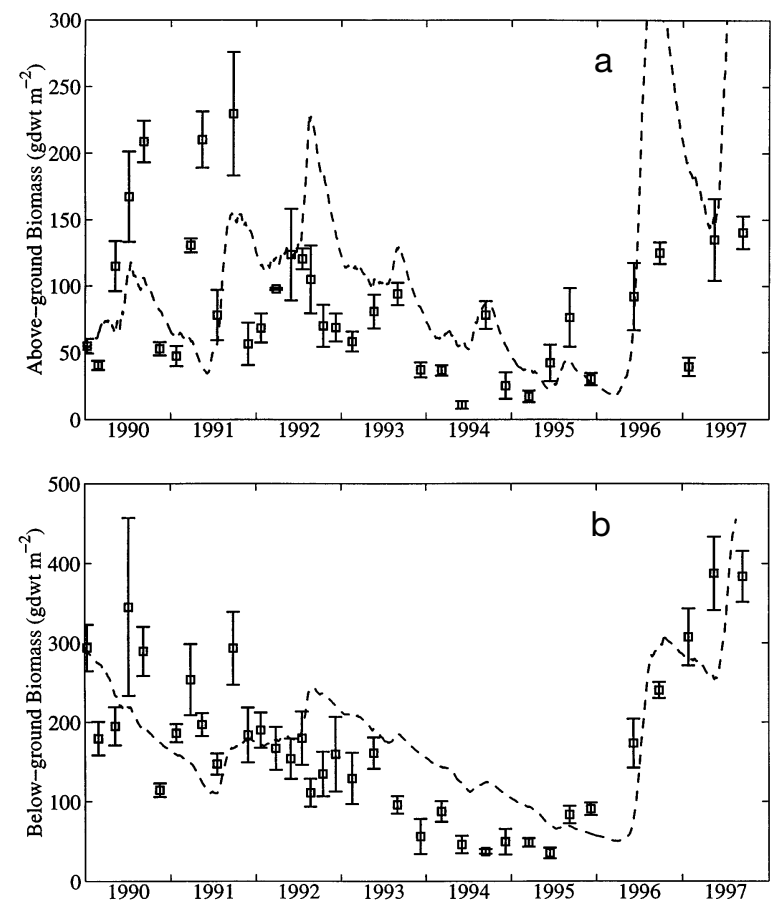

Fig. 5. Halodule wrightii. Comparison between observation $(\square, \pm$ SE) and model (dashed line) output of (a) above- and (b) below-ground biomass over the period 1990 to 1997 

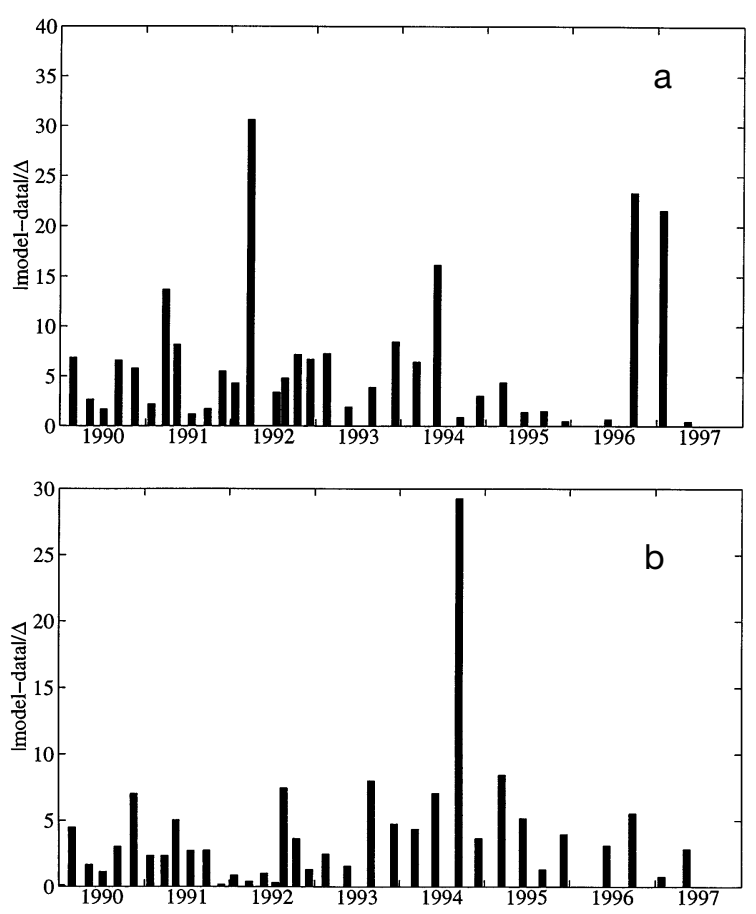

Fig. 6. Halodule wrightii. Absolute value of the residuals between the model and data normalized to the standard error of each data point (a) above- and (b) below-ground. Each bar on the plot shows how close the modeled biomass is to the measured value in units of the standard error of that measurement

the reduced irradiances resulting from the brown tide were having an apparent impact on the seagrass. The model generally over-predicted both above- and below-ground biomass, but tracked the rate of biomass decline well. The recovery of the below-ground biomass in 1996 and 1997 was also captured accurately by the model (Fig. 5b). However, the model strongly overpredicted the above-ground biomass during the same period (Fig. 5a).

Agreement between the model and the observations are variable but reasonably acceptable, with some notable exceptions (Fig. 6). The largest peaks (e.g., 1992: Fig. 6a) correspond to those points that have very small standard errors (cf. Fig. 5a). On the whole, the model appears to predict above- and below-ground biomass to within 5 to $7 \mathrm{SE}$.

\section{Model sensitivity: initial conditions and minimal light requirements}

Incorporating data assimilation into the model by using measured biomass to re-initialize the model at the start of each year greatly improved the agreement between model results and data (Fig. 7). Again, the same 3 time periods are apparent. Sudden jumps or discontinuities are evident in the model results (e.g., between 1992 and 1993). These are artifacts of re-initializing the model biomass at the start of each year. In 1990, the model results were identical to those without data assimilation (Fig. 5) since both models used the same initial conditions.

Differences between model results for which data assimilation was and was not used become apparent in 1991. The former produced lower above-ground biomass which better tracked the observed values. Agreement with below-ground biomass data was also improved (e.g., cf. Figs. 5 \& 7). In addition, the use of data assimilation reduces the residuals, especially for the period 1992 to 1997 (e.g., cf. Figs. 6 \& 8).

The minimum light requirements for Halodule wrightii were estimated by running the model for $1 \mathrm{yr}$ using different, constant light-attenuation coefficients and forcing the model using the surface light (Fig. 9). If $H$. wrightii received only $10 \%$ SI throughout the year, plant biomass rapidly decreased (Fig. 10). For $15 \%$ SI, there was some gain in biomass during the summer, but plant biomass at the end of the year was lower than at the start of the year. The results for $20 \%$ SI were
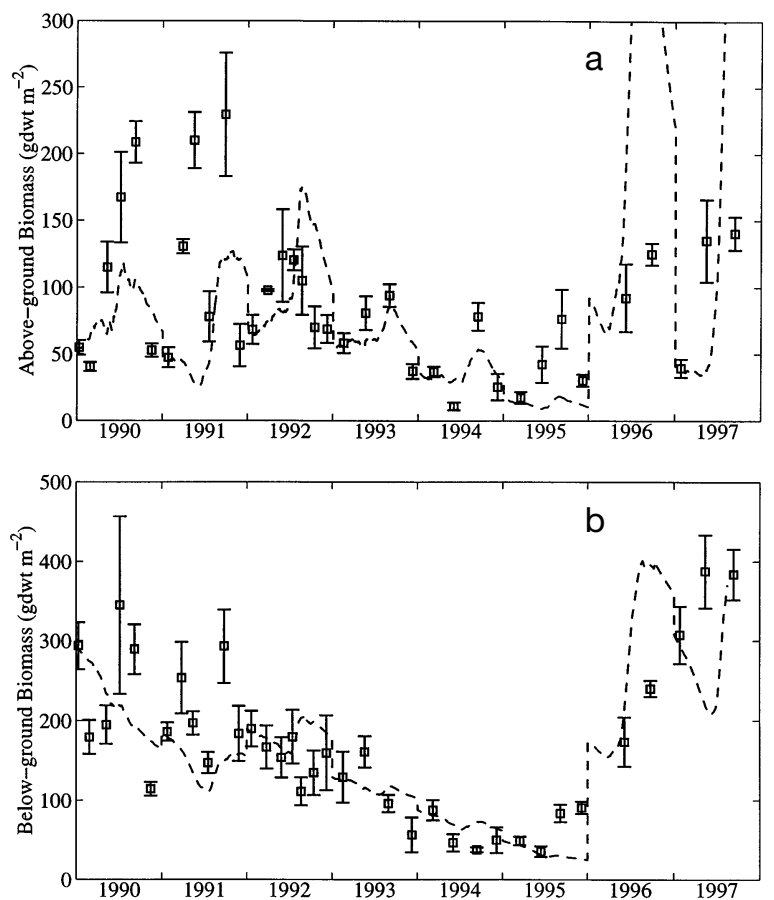

Fig. 7. Halodule wrightii. Comparison between observation $(\square, \pm \mathrm{SE})$ and model (dashed line) output of (a) above- and (b) below-ground biomass over the period 1990 to 1997. This model differs from that in Fig. 5 in that data-assimilation techniques have been incorporated into the model. Comparison with Fig. 5 shows better agreement between the Fig. 7 model and data, especially for the period 1992 to 1995 
similar to those for $15 \%$ SI, except that there was a slight net increase in biomass during the course of the year. This indicates that the minimum light requirement for $H$. wrightii lies between 15 and $20 \% \mathrm{SI}$, in
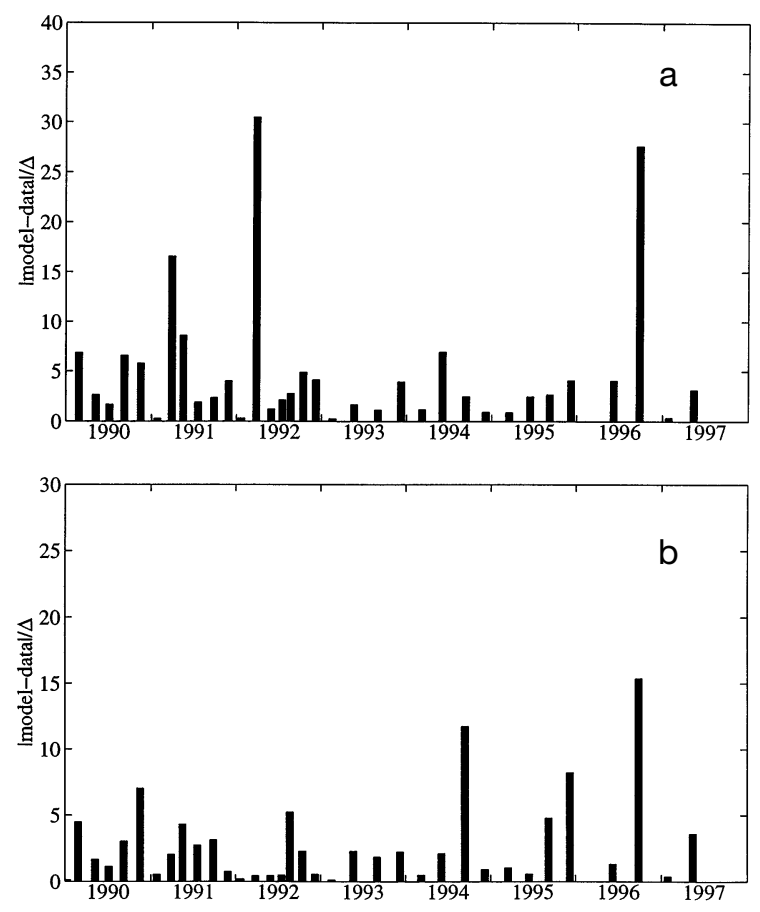

Fig. 8. Halodule wrightii. Absolute value of the residuals between the model with data-assimilation and data normalized to the standard error of each data point (a) aboveand (b) below-ground

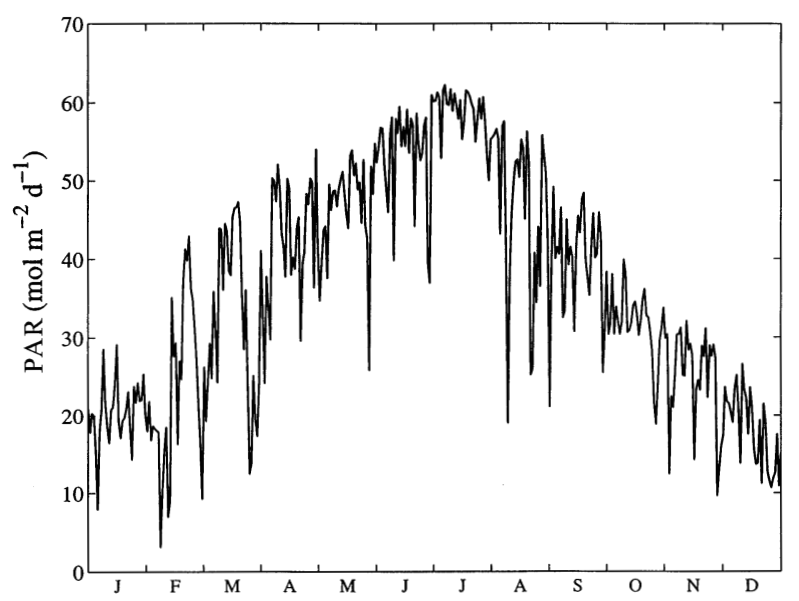

Fig. 9. Halodule wrightii. Daily SI (PAR, mol photons) for 1 yr. Data are a composite of surface irradiances measured in Lower Laguna Madre between August 1994 and February 1997. Values were obtained by averaging data measured on the same day from each year. Missing data were not replaced, so the number of data values used for each average varied
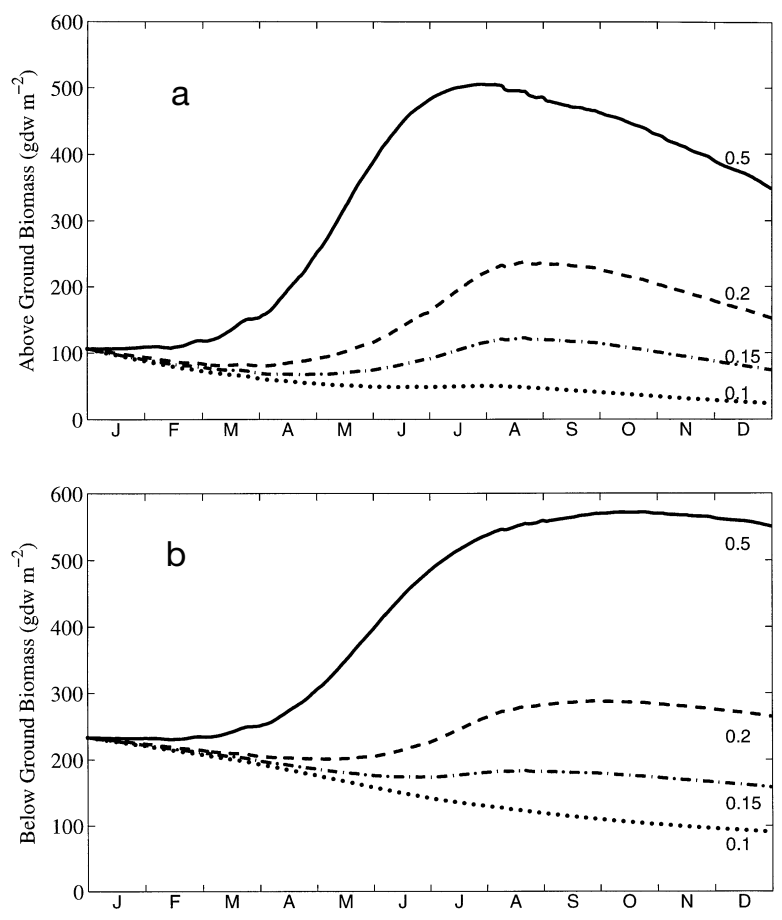

Fig. 10. Halodule wrightii. Light requirements for growth. Biomass modeled (a) above- and (b) below-ground obtained using various fractions of surface irradiance (SI): continuous line $=50 \%(k=0.46)$ SI at canopy level; dashed line $=20 \%$ $(k=1.07)$ SI at canopy level; dash-dotted line $=15 \%(\mathrm{k}=1.26)$ SI at canopy level; dotted line $=10 \%(k=1.54)$ SI at canopy level

agreement with previous observations for $H$. wrightii in Laguna Madre (Dunton 1994, 1996, Onuf 1996). The case for $50 \%$ SI is shown for comparison in Fig. 10.

\section{DISCUSSION}

\section{Model validity and overall performance}

The model we have presented is based on the assumption that light is the dominant factor determining seagrass growth and production (Zieman 1980). Given this, the model shows good agreement with the observed above- and below-ground biomasses during the period 1990 to 1997 (Fig. 5). PAR was used as the sole environmental forcing. However Zimmerman \& Mobley (1997) have put forward persuasive arguments that light 'quality' (i.e., spectral information) is also important for seagrass health. In particular, models based solely on PAR predict higher production than spectral models, particularly for high concentrations of water-column chlorophyll (P. Eldridge pers. comm), because both phytoplankton and seagrasses make use of the same region of the light spectrum. Unfortunately very little information is available for the spectral ab- 
sorbance properties of seagrass leaves, making a full spectral model difficult to implement at this time. In addition, such a model would require spectral absorbance characteristics of the suspended material in the water column. Some progress has been made towards developing such a model by calibrating standard parameterizations for the spectral attenuation coefficients for a particular region (Gallegos \& Kenworthy 1996).

The model does not uniformly over-predict or underpredict the observed biomass (Fig. 5). During the early part of the simulation (1990 and 1991), the model under-predicts both the above- and below-ground biomass; during the later part (1996 and 1997), the model over-predicts the above-ground biomass; during the central part of the simulation (1992 to 1995), the model over-predicts both above- and below-ground biomass. This variation in model performance suggests that some or all of the parameters held constant throughout the simulations may in fact vary with time. The lack of variation in these parameters will be partly compensated for in the values of $\tau, \delta$ and $\kappa$ obtained from optimization. This is because the model will not reproduce changes in biomass arising from changes in $P_{\text {max }}$ and $I_{k}$. Thus, any such changes in biomass can contribute to the determination of values for the other parameters.

One dramatic feature of the observed biomass is the rapid recovery of the below-ground biomass as the brown tide decreased in 1995 and 1996. The model captures this, but over-predicts the recovery in the above-ground biomass (Fig. 5a). Given the fact that the model was calibrated using data only from 1989, it is encouraging to see agreement between the model and field data for the increase in below-ground biomass.

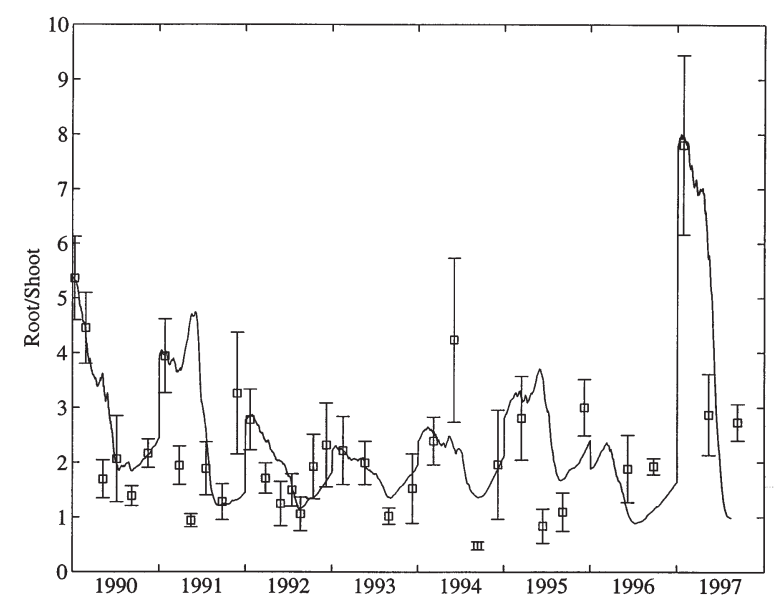

Fig. 11. Ratio of below- to above-ground (Root/Shoot) biomass for the observations ( $\square$ ) and the model results with data assimilation (line). Error bars represent standard errors derived from those of the biomass measured above- and belowground, calculated using standard propagation of errors
The over-prediction of the above-ground biomass is troublesome, and may be the result of several factors. One is the fact that, as mentioned above, the photosynthetic and respiration parameters were taken as constants.

Data-assimilation techniques have been used in this to work both estimate the values of certain parameters (Table 2) and to improve the predictive capabilities of the model (Fig. 7). Using data assimilation to calibrate a model requires a large amount of high-quality data in a model that accurately reflects the mechanics of the system being studied. Considerable care must be taken, since different optimization techniques can produce very different parameter values (Vallino 1998). This emphasizes the need for modeling and field programs that are complementary.

We also used data assimilation to help improve the predictive capabilities of the model. The method of reinitializing the model every year was crude. Without data assimilation, the simulation results diverge from the observations (Fig. 5). With data assimilation, however, the model is periodically brought back into step with the data (Fig. 7). It appears from Fig. 7 that the model drifts from the observed results after a period of $\leqslant 1 \mathrm{yr}$, that this is the period over which the model most accurately predicts the observed biomass.

Much of the biomass of Halodule wrightii lies below ground and is in a dynamic state. The ratio of below to above-ground biomass provides an indicator of the resource allocation of the plant. The model with data assimilation reproduces the observed ratio well (Fig. 11). This would indicate that even though a crude model of resource allocation has been used, when combined with a data-assimilation technique, a reasonable prediction of the resource allocation can be made.

The model is successful in predicting observed changes in above- and below-ground biomass over the course of a year using observed light data. This suggests that the model can be used to examine the effects of idealized changes in light using the synthetic SI and imposed values of the attenuation coefficient $k$. Seagrasses require a minimum level of light for maintenance and growth (Duarte 1991). For Halodule wrightii this has been estimated from field work as lying between 15 and $18 \%$ of SI (Dunton 1996, Kenworthy \& Fonseca 1996). The model predicts a similar range (Fig. 10); however this was produced by assuming that light attenuation $(k)$ in the water column was constant throughout the year. In reality, average monthly values for $k$ fluctuated, and in the Upper Laguna Madre lay between approximately $0.2 \mathrm{~m}^{-1}$ and 2 between 1989 and 1993.

The calibration of the model produced values (Table 2) for the carrying capacity $(\kappa)$, transport rate 
from above- to below-ground tissues $(\tau)$ and the rate of exudation of DOC $(\delta)$. The carrying capacity $(\kappa=667 \mathrm{~g}$ dry $\mathrm{wt} \mathrm{m}^{-2}$ ) is larger than the maximum above-ground biomass observed (approximately $250 \mathrm{~g}$ dry wt $\mathrm{m}^{-2}$ ). However, the model is driven entirely by light and there are many other factors (e.g., nutrient uptake) that can affect the total biomass an area can sustain. It is possible however that this high value for the carrying capacity explains in part the high values for the modeled above-ground biomass in 1996 and 1997.

How long can Halodule wrightii tolerate chronic levels of low light? No changes in seagrass distribution were detected in the Upper Laguna Madre between surveys made in 1988 and 1992 (Onuf 1996), but between 1992 and 1995 more than $9.4 \mathrm{~km}^{2}$ of seagrass vegetation had been lost at depths $>1.4 \mathrm{~m}$. At depths $<1.4 \mathrm{~m}$, biomass decreased substantially and the plants relied heavily on stored carbon reserves (Dunton 1994). When the brown tide declined in 1996 and 1997, $H$. wrightii was able to recover quickly. This is especially true of the below-ground biomass, which returned to almost pre-brown tide levels within 18 mo.

\section{Toward a whole-plant model: resource allocation and carbon sinks}

The ability of Halodule wrightii to respond rapidly to favorable light levels may help it survive periods of low light levels. Even though average light levels dropped as low as $9 \%$ SI during the brown tide, there were periods where as much as $50 \%$ SI reached the bottom (Dunton 1994, Onuf 1996). During the early period of the brown tide, the seagrass presumably used previously stored material for maintenance (Dunton 1994). As this material was depleted, the plants would find it harder to survive. If the rapid increase in belowground biomass seen at the end of the brown tide is indicative of an allocation strategy of the plant, then the plant may be able to use short periods of high light to replenish these reserves, allowing it to survive longer at low average light levels.

Photosynthesis in seagrass leaves must support not only the leaf tissue but also considerable non-photosynthetic below-ground biomass. Therefore, the plant must be able to transport carbon from the leaves to the roots and rhizomes. Measurements of translocation for Halodule wrightii are scant and varied. For example, Moriarty et al. (1986) found that under optimal irradiance, 6 to $26 \%$ of the carbon fixed by the leaves had been translocated to the below-ground tissues after $3 \mathrm{~h}$. After 4 h, $7 \%$ had been translocated, and after $6 \mathrm{~h}$ the proportion had risen to $28 \%$. These values should be compared with the value we obtained for transport between above- and below-ground material. The cali- bration of the model produces a value of $\tau=34 \%$ of gross primary production. This value is higher than that seen in the experiments, but represents transport in only 1 direction, rather than the net transport to below-ground material that was measured by Moriarty et al. (1986). In addition to vertical transport, translocation will also occur horizontally. Terrados et al. (1997) estimated that growth at the apical meristem of a Cymodocea nodosa rhizome was supported by resources originating from shoots further than $50 \mathrm{~cm}$ from the growth site. So, to properly represent the dynamics of carbon (and nutrients) within the plant, models of seagrasses must include translocation of resources to adequately account for the use of the plants resources. Some success has been achieved in modeling transport in terrestrial plants (Wilson 1988). These models often require a good knowledge of carbon and nitrogen dynamics in the plant as well as a parameterization of flow resistances.

The 1-directional linear model of transport we have used is obviously a major simplification. Although transport from above- to below-ground tissue is considered, flow in the opposite direction is not. Consequently, the model does not allow for the usage of material stored in the rhizome to supplement photosynthetically produced carbon during times of low irradiance. The model assumes that transport occurs only from the above- to the below-ground tissue. This is obviously unrealistic. Seagrasses can use material stored in the rhizome during periods of stress. For example, rhizome carbohydrate concentrations in Thalassia testudinum increase during the summer and decrease during the winter and spring (Lee \& Dunton 1996). The summer increase has been attributed to production and storage of starch, while the decreases have been linked to utilization of these reserves for maintenance and growth (Dawes \& Lawrence 1980, Lee \& Dunton 1996). One might suspect that this would cause the model to predict a more rapid decrease in biomass when PAR is low. However, the simulations do not seem to indicate this (Fig. 5). A possible reason is that this loss of carbon is being counterbalanced in the model by an overproduction arising from using PAR instead of a spectral model.

The exudation of DOC from the below-ground tissue was also determined during the calibration of the model. This value $(\delta=0.001)$ is much lower than that observed by Moriarty et al. (1986), indicating that further development of the model is required in this area. In oligotrophic environments, seagrasses appear to compensate for nutrient limitation by increasing root surface area to facilitate nutrient uptake (Lee \& Dunton 1999). Evidence for significant release of DOC by below-ground tissues was demonstrated by Ziegler \& Benner (1998) in the Lower Laguna Madre. They noted 
that the heterotrophic activity of the water column was fueled by release of DOC from seagrass-dominated sediments. These observations also agree with those of Lee \& Dunton (1999), who found that over $50 \%$ of the nitrogen taken-up by Thalassia testudinum was rereleased by the plant. The excess carbon predicted in our model may reflect our underestimate of belowground tissue exudation of DOC into sediments, which appears to be significant. Consequently, this model provides the framework for combining hypothetical models with experimental work that can contribute to our overall understanding of seagrass productivity.

\section{CONCLUSIONS}

In contrast to previous seagrass models, our approach to the development of a quantitative and reasonably accurate production model for the subtropical seagrass Halodule wrightii was unique in several respects.

First, the model is relatively simple. It does not take into account many of the complex relationships associated with nutrient loading and light attenuation caused by phytoplankton, epiphytes, and benthic algae. It is specific to the Laguna Madre, which despite the persistence of a long-lived brown tide algal bloom, is a hypersaline lagoon of oligotrophic character. Consequently, the importance of biological interactions are minimized and physical factors (e.g., light and temperature) become most important.

Second, the model takes a whole-plant approach. The dominance of below-ground tissues with respect to total seagrass biomass has long been recognized but seldom considered in physiological or ecological studies. Since below-ground tissues appear to play critical roles in the biogeochemical processes that occur in the sediments, as well as regulate processes in the overlying water column, it is important to include this component in seagrass models. From a resource management perspective, the inclusion of below-ground tissues is critical for a predictive model.

Third, our model links theoretical and empirical knowledge with 9 yr of actual field measurements collected on a regular basis. The field data provided an unprecedented opportunity to validate model predictions, identify gaps in our knowledge, and reassess the role of various processes that contribute to our ability to apply models in coastal resource management. The results of this joint effort revealed that subsequent seagrass modeling efforts should not ignore the sizable below-ground component or the role of light as a major abiotic factor, especially in nutrient-limited environments. The predictive power of seagrass models as tools for effective management decisions appear to be largely based on our ability to provide accurate estimates of water-column light attenuation and fundamental knowledge of the physiological characteristics of seagrasses.

Acknowledgements. This project was funded by the US Army Corps of Engineers. We would like to thank Peter Eldridge, Jim Kaldy, George Jackson and Ruben Solis for useful discussions and encouragement as well as the anonymous reviewers for their comments. K.H.D. gratefully acknowledges K. Jackson, J. Kaldy, K.-S. Lee and S. Sconberg for many years of dedicated assistance in the field. A.B.B. would like to thank Ian Anderson and Andrew Giddings whose music made the many long nights spent working at the computer a tolerable experience.

\section{LITERATURE CITED}

Anderson DLT, Sheinbaum J, Haines K (1996) Data assimilation in ocean models. Rep Prog Phys 59:1209-1266

Brown CA (1997) Environmental monitoring of dredging and processes in Lower Laguna Madre, Texas: data report, September, 1994-May, 1997. Conrad Blucher Institute, Texas A\&M University, Corpus Christi (Tech Rep)

Caffrey JM, Kemp WM (1991) Seasonal and spatial patterns of oxygen production, respiration and root-rhizome release in Potamogeton perfoliatus L. and Zostera marina L. Aquat Bot 40:109-128

Carlson PR Jr, Yarbro LA, Barber TR (1994) Relationship of sediment sulfide to mortality of Thalassia testudinum in Florida Bay. Bull Mar Sci 54:733-746

Christiansen C, Christofferson H, Dalgaard J, Norberg R (1981) Coastal and nearshore changes correlated with diebacks in eelgrass (Zostera marina L.). Sediment Geol 28: 163-173

Dawes CJ, Guiry MD (1992) Proximate constituents in the seagrasses Zostera marina and $Z$. noltii in Ireland: seasonal changes and the effect of blade removal. PSZN I: Mar Ecol 13:307-315

Dawes CJ, Lawrence JM (1979) Effects of blade removal on the proximate composition of the rhizome of the seagrass Thalassia testudinum Banks ex Konig. Aquat Bot 7: 255-266

Dawes CJ, Lawrence JM (1980) Seasonal changes in the proximate constituents of the seagrasses Thalassia testudinum, Halodule wrightii and Syringodium filiforme. Aquat Bot 8:371-380

Dennison WC, Alberte RS (1982) Photosynthetic responses of Zostera marina L. (eelgrass) to in situ manipulations of light intensity. Oecologia 55:137-144

Dennison WC, Orth RJ, Moore KA, Stevenson JC, Carter V, Kollar S, Bergstrom PW, Batuik RA (1993) Assessing water quality with submerged aquatic vegetation: habitat requirements as barometers of Chesapeake Bay health. BioScience 43:86-94

DeYoe HR, Suttle CA (1994) The inability of the Texas brown tide alga to use nitrate and the role of nitrogen in the initiation of a persistent bloom of this organism. J Phycol 30: 800-806

Duarte CM (1991) Seagrass depth limits. Aquat Bot 40: 363-377

Dunton KH (1990) Production ecology of Ruppia maritima L.s.l. and Halodule wrightii Aschers. in two subtropical estuaries. J Exp Mar Biol Ecol 143:147-164 
Dunton KH (1994) Seasonal growth and biomass of the subtropical seagrass Halodule wrightii in relation to continuous measurements of underwater irradiance. Mar Biol 120:479-489

Dunton KH (1996) Photosynthetic production and biomass of the subtropical seagrass Halodule wrightii along an estuarine gradient. Estuaries 19:436-447

Dunton KH, Tomasko DA (1994) In situ photosynthesis in the seagras Halodule wrightii in a hypersaline subtropical lagoon. Mar Ecol Prog Ser 107:281-293

Durako MJ, Kuss KM (1994) Effects of Labyrinthula infection on the photosynthetic capacity of Thalassia testudinum. Bull Mar Sci 54:727-732

Fong P, Harwell MA (1994) Modeling seagrass communities in tropical and subtropical bays and estuaries: a mathematical model synthesis of current hypotheses. Bull Mar Sci 54:757-781

Fong $\mathrm{P}$, Jacobson ME, Mescher MC, Lirman D, Harwell MC (1997) Investigating the management potential of a seagrass model through sensitivity analysis and experiments. Ecol Appl 7:300-315

Fourqurean JW, Zieman JC (1991) Photosynthesis, respiration and whole plant carbon budget of the seagrass Thalassia testudinum. Mar Ecol Prog Ser 69:161-170

Gallegos CL, Kenworthy WJ (1996) Seagrass depth limits in the Indian Rive Lagoon (Florida, U.S.A.): application of an optical water quality model. Estuar Coast Shelf Sci 42: 267-288

Grace A (1993) Optimization toolbox: for use with Matlab. Mathworks Inc, Natick, MA

Henley WJ (1993) Measurement and interpretation of photosynthesis light-response curves in algae in the context of photoinhibition and diel changes. J Phycol 29:729-739

Herzka SZ, Dunton KH (1997) Seasonal photosynthetic patterns of the seagrass Thalassia testudinum in the western Gulf of Mexico. Mar Ecol Prog Ser 152:103-117

Jassby AD, Platt T (1976) Mathematical formulation of the relationship between photosynthesis and light for phytoplankton. Limnol Oceanogr 21:540-547

Kenworthy WJ, Fonseca MS (1996) Light requirements of seagrasses Halodule wrightii and Syringodium filiforme derived from the relationship between diffuse light attenuation and maximum depth distribution. Estuaries 19: $740-750$

Kirk JTO (1994) Light and photosynthesis in aquatic environments, 2nd edn. Cambridge University Press, Cambridge

Lawson LM, Spitz YH, Hofmann EE, Long RB (1995) A data assimilation technique applied to a predator-prey model. Bull Math Biol 57:593-617

Lawson LM, Hofmann EE, Spitz YH (1996) Time series sampling and data assimilation in a simple marine ecosystem model. Deep-Sea Res II 43:625-651

Lee KS, Dunton KH (1996) Production and carbon reserve dynamics of the seagrass Thalassia testudinum in Corpus Christi Bay, Texas, USA. Mar Ecol Prog Ser 143: 201-210

Lee KS, Dunton KH (1999) Inorganic nitrogen aquisition in the seagrass Thalassia testudinum: development of a whole-plant nitrogen budget. Limnol Oceanogr 44: $1204-1215$

Madden CJ, Kemp WM (1996) Ecosystem model of an estuarine submerged plant community: calibration and simulation of eutrophication responses. Estuaries 19:457-474

Moriarty DJW, Iverson RL, Pollard PC (1986) Exudation of organic carbon by the seagrass Halodule wrightii Aschers. and its effect on bacterial growth in the sediment. J Exp Mar Biol Ecol 96:115-126
Onuf CP (1994) Seagrasses, dredging and light in Laguna Madre, Texas, U.S.A. Estuar Coast Shelf Sci 138:219-231

Onuf CP (1996) Seagrass responses to long-term light reduction by brown tide in upper Laguna Madre, Texas: distribution and biomass patterns. Mar Ecol Prog Ser 138: 219-231

Orth RJ, Heck KL Jr, van Montfrans J (1984) Faunal communities in seagrass beds: a review of the influence of plant structure and prey characteristics on predator-prey relationships. Estuaries 4:339-350

Pirc H (1985) Growth dynamics in Posidonia oceanica (L.) Delile: I. Seasonal changes of soluble carbohydrates, starch, free amino acids, nitrogen and organic anions in different parts of the plant. PSZN I: Mar Ecol 6:141-165

Pirc H (1989) Seasonal changes in soluble carbohydrates, starch, and energy content in Mediterranean seagrasses. PSZN I: Mar Ecol 10:97-105

Pulich WM Jr (1980) The ecology of a hypersaline lagoon: the Laguna Madre. In: Fore PL, Peterson RD (eds) Proceedings of the Gulf of Mexico coastal ecosystems workshop. U.S. Fish \& Wildlife Service, Albuquerque, NM (FWS/ OBS-80/30)

Pulich WM Jr (1999) Seagrass Conservation Plan for Texas. Texas Parks \& Wildlife Department, Austin, TX (Tech Rep)

Pulich WM Jr, White WA (1991) Decline of submerged vegetation in the Galveston Bay system: chronology and relationship to physical processes. J Coast Res 7:1125-1138

Quammen ML, Onuf CP (1993) Laguna Madre: seagrass changes continue decades after salinity reduction. Estuaries 16:302-310

Ralph PJ, Burchett MD, Pulkownik (1992) Distribution of extractable carbohydrate reserves within the rhizome of the seagrass Posidonia australis Hook f. Aquat Bot 42:385-392

Richardson K, Beardall J, Raven JA (1983) Adaptation of unicellular algae to irradiance: an analysis of strategies. New Phycol 93:157-191

Robblee MB, Barber TR, Carlson PR, Durako MJ, Fourqurean JW, Muehlstein LK, Porter D, Yarbro LA, Zieman RT, Zieman JC (1991) Mass mortality of the tropical seagrass Thalassia testudinum in Florida Bay (USA). Mar Ecol Prog Ser 71:297-299

Short FT (1980) A simulation model of the seagrass production system. In: Phillips RC, McRoy CP (eds) Handbook of seagrass biology: an ecosystem perspective. Garland STPM Press, New York p 277-295

Smith RD, Dennison WC, Alberte RS (1984) Role of seagrass photosynthesis in root aerobic processes. Plant Physiol 74: 1055-1058

Stockwell DA, Buskey EJ, Whitledge TE (1993) Studies on conditions conducive to the development and maintenance of a persistent brown tide in Laguna Madre, Texas. In: Smayda TJ, Shimizu TJ (eds) Toxic phytoplankton blooms in the sea. Elsevier Science Publishers, New York, p 693-698

Terrados J, Duarte CM, Kenworthy WJ (1997) Is the apical growth of Cymodocea nodosa dependent on clonal integration? Mar Ecol Prog Ser 158:103-110

Thornley JHM, Johnson I (1990) Plant and crop modelling: a mathematical approach to plant and crop physiology. Oxford University Press, Oxford

Valiela I (1995) Marine ecological processes, 2nd edn. Springer-Verlag, New York

Vallino JJ (2000) Improving marine ecosystem models: use of data assimilation and mesocosm experiments. J Mar Res 58:117-164

Wetzel RL, Neckles HA (1986) A model of Zostera marina L. photosynthesis and growth: simulated effects of selected 
physical-chemical variables and biological interactions. Aquat Bot 26:307-323

Wilson JB (1988) A review of evidence on the control of shoot:root ratio, in relation to models. Ann Bot 61:433-449

Ziegler S, Benner R (1998) Ecosystem metabolism in a subtropical, seagrass-dominated lagoon. Mar Ecol Prog Ser 173:1-12

Zieman JC, Wetzel RG (1980) Productivity in seagrass: methods and rates. In: Phillips RC, McRoy CP (eds) Handbook of seagrass biology. Garland STPM Press, New York, p 87-116

Editorial responsibility: Kenneth Heck Jr (Contibuting Editor), Dauphin Island, Alabama, USA
Zieman JC, Fourqurean JW, Iverson RL (1989) Distribution, abundance and productivity of seagrasses and macroalgae in Florida Bay. Bull Mar Sci 44:292-311

Zimmerman RC, Mobley CD (1997) Radiative transfer within seagrass canopies: impact on carbon budgets and light requirements. In: Ackleson SG (ed) Ocean optics XIII. Proc SPIE, Vol 2963, Bellingham, WA, p 331-336

Zimmerman RC, Cabello-Pasini A, Alberte RS (1994) Modeling daily production of aquatic macrophytes from irradiance measurements: a comparative analysis. Mar Ecol Prog Ser 114:185-196

Submitted: December 17, 1999; Accepted: June 27, 2000 Proofs received from author(s): November 27, 2000 